\title{
Analyzing Poverty and Resilience to Shocks of Bamboo Producing Smallholders in North-West Ethiopia
}

\author{
Dagnachew Walle ${ }^{1}$ Abrham Seyoum ${ }^{2}$ \\ 1.Arbaminch University \\ 2.Addis Ababa University, Ethiopia
}

\begin{abstract}
Exploring and understanding the multiple purposes of bamboo on enhancing and sustaining the livelihood of smallholders' through multidimensional poverty reduction and mitigating shocks is so crucial. Data analysis was done using both descriptive and econometric analysis using the software package of stata thirteen. As the result revealed that, pests affecting crops and the large increase in input price were relatively high frequent shocks in the households. As the finding shows that, 29.13 percent of the smallholder farmers were multidimensional poor. To examine resilience to shocks of smallholder, RIMA models using factors analysis was run. As the factory analysis explored that, 233(47.94 percent) of smallholder were resilient to shocks and 253(52.06 percent) were non-resilient. Among bamboo, users80.15percent were resilient while the non-user (32.92percent). The study recommends on the need for policy and strategies design to enhance the well-being of smallholder and to build resilience to shocks, organizing bamboo producer smallholder in a bamboo cooperative, providing extension service proper processing of bamboo value chain should have to a policy in North- West Ethiopia.
\end{abstract}

DOI: $10.7176 /$ JPID/59-01

Publication date: February $28^{\text {th }} 2021$

\section{INTRODUCTION}

Among the various resources in the world, bamboo is one of the most important. It is a global fact that rural households have an attachment to natural resources in general and to forest particular for consumption and nonconsumption purposes. Bamboo has taken an attention for its numerous uses and its advancing new applications for the last twenty years on the globe Chirwa and Meliczek (2014). It offers substantial economic, social, and environmental uses, fuel wood, timber and non-timber products, construction materials, medicinal uses, and cultural values for local communities particularly for smallholders (Mohammadi et al., 2010, INBAR, 2010). Around the globe above 600 million people make their income from bamboo, and about 2.5 billion people based their life on bamboo with an estimated value of US \$ 7 billion per year FAO, (2005). To this effect, bamboo has enormous potential for enhancing the environment, resilience to shocks, reducing poverty, UNIDO, (2009). Particularly, the bamboo sector has the potential to end poverty and mitigating shocks. In addition to this as, INBAR (2015) stated in its report by promoting bamboo planting and cultivation can help the poor provide with a natural resource that they have access to and ownership over and principally resilient to natural and manmade shocks and reduce the severity of poverty.

Among the definition of poverty still no consensus due to its multifaceted nature, spatial, temporal, and personal differences Teshome, (2012). But in this article, it means that multidimensional deprivation in education, health, and living standards on bamboo producing smallholders. Currently, the prevalence of poverty in Ethiopia is $0.564 \mathrm{MPI}$, particularly $0.588 \mathrm{and} 0.584 \mathrm{MPI}$ in Amhara and Benishangul-Gumuz regional states respectively Alkire, S. and Robles, G. (2016).

Shocks are occasions that adversely distress household prospects. These may be tremendously shocking natural events such as drought, Flood and soil erosion, Crop diseases, and Livestock diseases Tesfaye Gedefaw (2013). Among such shocks in Ethiopia including Awizone from Amhara and in Benshangulgumuze regional states drought has long lasting history and recently in 2015 it devastate livelihoods multidimensionality so 10.2 million people in need of food aid, 435,000 children are in need of treatment for severe acute malnutrition, more than 1.7 million children, pregnant women and lactating women are in requisite of supplemental feeding, more than 5.8 million populaces are in requisite of emergency water, more than 2 million children on average were dropping out their school attendance UNICEF, (2016).Despite these deprivations are pillars of sustainable development objective United Nations, (2016).

However, Ethiopia is one of the countries in the world gifted a huge bamboo resource base Embaye (2000), Kelbessa et al. (2000) and Yemishaw et al. (2009). The country has about one million hectares of woodland bamboo, and from which 7\% covers the world total and 86\% of the African total Embaye et al. (2003), FAO (2006) and Wang (2006) and particularly in Awizone, Amhara regional state2380 and 77947 in Assossa, Benshangulgumuze regional state in hectare Ensermu et al., (2000). It was valued that over 1.2 billion USD can be made each year if the country's bamboo supply is appropriately utilized INBAR (2010). According to Arsema, (2008) finding that the framers of the Shedem area in the Bale Zone of Ethiopia made 47\% of their yearly income from collecting and marketing of bamboo culms. Yenesew Assaye et al., (2013) studied the socioeconomic 
contribution of high land bamboo for household livelihood in Banja, district, northwestern, Ethiopia, and he revealed that the contribution of bamboo to the HHs' annual income is about $48.7 \%$, and much more power full than other timber product forests. However, regarding its massive and higher potential is limited in income generation and serve as a means to resilience to shocks due to the existing marketing system of the bamboo sector is informal as such there is no interwoven system between product markets at local level and central markets.

Different researchers examine the contribution of bamboo on income generation and means of rural livelihood in the country, Ethiopia and particularly in north-west Ethiopia. For example, a research conducted in 2006 at bule district, gedeo zone, SNNPR by Fekadu Tarekegn discovered that the support of bamboo to the gross household income was found to be only $5.6 \%$ of the total following crop and livestock production, which is one-fourteenth of the income from agriculture. Similarly the study carried on the Bale zone at Shedem Kebele revealed that bamboo was collected by $99 \%$ of 362 respondent households and it's used as a secondary source of income next to agricultural earnings Tinsley and Bridget (2014). The income generating from bamboo subsidizes more to lower income smallholders, which accounts about $38 \%$ and used as a means of alleviating poverty.

The bulk of the empirical evidence available for the analysis of bamboo potential focused only the annual income earning from their resource and they did. Assess the poverty and resilience to shocks smallholders producing bamboo using multi-dimensional approaches. Consequently, this study was employed multidimensional poverty index and resilience index measurement analysis (RIMA) model to analyze multidimensional poverty and resilience to shocks of bamboo producing smallholders and the bamboos multifaceted purpose of ending poverty and mitigating shocks. In line with this, this study used as a bench mark of literature review for further study and it contribute its own role in academic arena.

The specific objectives of the paper are 1) Analyses the multidimensional poverty status of bamboo producing smallholders, 2) Identify the intensity and frequency of shocks facing bamboo producing smallholders and Examine resilience to shocks of bamboo producing smallholders. By addressing these inquire; this paper has its own significant role in creating a chance for those smallholders to be diversifying their agricultural systems, for researchers show how to measure multidimensional poverty and resilience to shocks. More over this paper has a crucial role in providing full information for policy makers to incorporate bamboo resources as a policy option to mitigate multidimensional poverty and resilience to shocks of smallholders.

\section{Study areas, data sources and Sampling methods}

This study is based on primary and secondary data from North-west Ethiopia of both high land and lowland bamboo species potential areas, particularly Amhara and Benshangulgumuze regional states in 2016/2017. The survey was implimented two zones in Amhara and one zone from Benshangulegumuze. In both regions multistage sampling procedure was employed to select respondents. In Amhara a sample consists a total of 344 and from Benshangulgumuze 142 respondents were concidered.

\section{ANALYZING MULTIDIMENSIONAL POVERTY STATUS OFBAMBOO PRODUCING SMALLHOLDERS}

Poverty has been traditionally measured in unidimensional. Among the unidimensional measures Sen's Capability approach has taken a lion share and widely applied. This method comprises non-income constituents such as life expectancy, literacy and infant mortality to measure poverty. Sen (1985) focused on the superiority of life and underlined on the eradicating of problems so that people could have more freedom to function. He elucidated basic capability as the freedom to do basic activities essentially to eliminate poverty.

The capabilities approach (Sen, 1979, 1983, 1985, 1997) criticizes poverty measurements based solely on possessions because resource accessibility says not anything about what people do or may well do with those possessions. Abilities thus designate people's possibilities or degrees of freedom to satisfy certain functions, such as being well fed, obtaining employment and education. In this motivation, poverty is viewed as powerlessness to achieve certain basic functions. In line with these various studies revealed that in both developing and developed country's estimation of poverty using unidimensional poverty measurements fail to adequately capture the proportion of the poor within the overall populace. This is because among other motives it fails to consider the multi-dimensional nature of poverty (Sen 2000; Alkire and Santos 2010). According to Sen (2000), human lives are maltreated and reduced in all classes of different ways, and the principal task is to recognize that deprivations of very different categories have to be accommodated within a general all-embracing framework. Thus, the view that poverty is composite and multi-dimensional renders the income and expenditure measurement approach inadequate.

Therefore, nowadays to analyze the multidimensional deprivation, multidimensional poverty indices (MPI) have been employed as preferred measurements of poverty due to their own advantages over unidimensional measurements. This is because of MPIs multifaceted advantages over other poverty measurement methods such as unidimensional poverty measures in income do not assurance an enhancement in other dimensions like health, education and living standard. From the perspective of the capability approach, poverty is not the only 
dispossession of income reasonably it is lack of other social indices, i.e. Health, education and other capabilities, Multidimensional poverty does not oscillate due to inflation Alkire and Santos (2010).MPI also has an advantage over HDI (Human Development Index) such as HDI is a macro miracle which measures welfare at the country level. It uses country means to reflect collective dispossessions in health, education, and standard of living. Although it can be disaggregated at micro group or regions such as district level or state level but the central problem is that it depends on macro data. These are combined in a way such that the data directly are not used to calculate the index. It could not pinpoint specific individuals, households or larger groups of people as equally deprived. But the MPI uses household as the unit of analysis, which is then summed up to country level. The MPI addresses the poverty circumstances by picking up how many people experience overlying dispossessions (prevalence) and exactly how many dispossessions they face meanly (intensity). By the way it is constructed, accessible information can be used proficiently and loss of information is diminished. The MPI can be classified by the indicator to illustrate how the components of multidimensional poverty fluctuations for different regions, ethnic groups with useful implications for policy. Moreover, MPI has miracle welfares such as monitor the standard and components of poverty, target the poorest more efficiently, pinpoint poverty traps and chronic poverty, and relate the composition of deprivations in different areas or for different ethnic groups, and kinds of household, sabina alkire (2009).

As a result of these multiple functions, Multidimensional Poverty Index (MPI) is considered to measure critical poverty (Alkire \& Santos, 2010) and multidimensional poverty indices are used as a guide intended to measure critical poverty. Critical poverty denotes that multiple deprivations in terms of education, health, and living standards within their observable indicators such as if one doesn't accomplish five years of schooling in the household, does one school- age child joined in school, does one member from the household is malnourished, from the household does one or above children under 5 years have died, does the household at least accessible to electric, households does not access to solar energy, if households does not access to clean drinking water, if households does not accessible to adequate sanitation, if households does uses traditional energy for cooking (dung, fire wood, Charcoal), and if households house floor construct with mud, sand, dung Human development report (2015).

To analyze multifaceted poverty status of bamboo producing smallholders, the multidimensional poverty index employed for analysis using the software package of Stata version thirteen. Clearly, it presents as;

\begin{tabular}{|c|c|c|}
\hline Dimensions & Indicators of dimensions & measurements \\
\hline \multirow[t]{2}{*}{ Education } & $\begin{array}{l}\text { No one has completed five years of } \\
\text { schooling in the household }\end{array}$ & $\begin{array}{l}1=\text { no hh member complete five year schooling } \\
0=\text { otherwise }\end{array}$ \\
\hline & $\begin{array}{l}\text { At least one school- age child not } \\
\text { enrolled in school }\end{array}$ & $\begin{array}{l}1=\text { if school age chilled doesn't enrolled in school } \\
0=\text { otherwise }\end{array}$ \\
\hline \multirow[t]{2}{*}{ Health } & $\begin{array}{l}\text { At least one member is malnourished } \\
\text { with in the } 12 \text { months }\end{array}$ & $\begin{array}{l}1=\text { if malnourished in kcal. } \\
0=\text { otherwise }\end{array}$ \\
\hline & $\begin{array}{l}\text { One or more children under } 5 \text { years } \\
\text { have died within } 12 \text { months }\end{array}$ & $\begin{array}{l}1=\text { if under five age child died } \\
0=\text { otherwise }\end{array}$ \\
\hline \multirow[t]{6}{*}{$\begin{array}{l}\text { Living } \\
\text { standards }\end{array}$} & No access to electric & $\begin{array}{l}1=\text { no access } \\
0=\text { otherwise }\end{array}$ \\
\hline & No access to solar energy & $\begin{array}{l}1=\text { no access } \\
0=\text { otherwise }\end{array}$ \\
\hline & No access to clean drinking water & $\begin{array}{l}1=\text { no access within } 30 \text { minut walking } \\
0=\text { otherwise }\end{array}$ \\
\hline & No access to adequate sanitation & $\begin{array}{l}1=\text { no access } \\
0=\text { otherwise }\end{array}$ \\
\hline & $\begin{array}{l}\text { Household uses dirty cooking fuel } \\
\text { (dung, fire wood, Charcoal) }\end{array}$ & $\begin{array}{l}1=\text { no access to electric cooking fuel } \\
0=\text { otherwise }\end{array}$ \\
\hline & $\begin{array}{l}\text { Household has construct his house } \\
\text { floor with dung, sand, mud }\end{array}$ & $\begin{array}{l}1=\text { no accessible } \\
0=\text { otherwise }\end{array}$ \\
\hline
\end{tabular}

Based on this information the head count ratio, intensity of poverty MPI value and contribution of dimensions for deprivation were done as the following;

The headcount ratio $(\mathbf{H})$ is the percentage of the multidimensionality poor in the populace:

$$
H=\frac{q}{n}
$$

Where, $\mathrm{q}$ is the number of people who are multidimensionality poor and $\mathrm{n}$ is the overall populace.

The intensity of poverty (A) represents the proportion of the weighted constituent indicators in which, meanly 
deprived

$A=\frac{\sum_{\mathrm{i}}^{\mathrm{q}} \mathrm{ci}}{q}$

Where, ci is the deprivation score that the ith deprived individual involvements.

The MPI value is the result of two measures: the multifaceted poverty headcount ratio and the intensity of poverty.

$$
M P I=H * A
$$

The contribution of dimension $\mathbf{j}$ to multidimensional poverty can be stated as

contrib $j=\frac{\frac{\sum_{1}^{q} c i j}{n}}{M P I}$

\section{EXAMINING RESILIENCE OF BAMBOO PRODUCING SMALLHOLDERS'}

Resilience to shocks is a crucial concept to analyze the bulk of smallholders to survive with, familiarize and benefit from it. Knowledge and experience of smallholders to shocks provide a prominent environment to policymakers to design policies with the shocks. Therefore quantitatively analyzing smallholder's resilience is the key point. But the main problem associated with resilience can't be measured directly due to its latent variable nature. The means of detecting this problem is that specifying resilience as a latent variable (Alinovi et al, 2010).

According to Alinovi et al., (2008 and 2010) resilience index, the household resilience index measurement and analysis (RIMA) model were determined by IFA, ABS, AST, SSN, and AC.

$\mathrm{RI}=\mathrm{f}(\mathrm{IFAi}, \mathrm{ABSi}, \mathrm{AST}$, SSNi, ACi)

Where, $\mathrm{R}=$ resilience, $\mathrm{IFA}=$ Income and food access, $\mathrm{ABS}=$ Access to basic services, $\mathrm{SSN}=\mathrm{Social}$ safety nets, $\mathrm{AST}=$ Assets, and $\mathrm{AC}=$ Adaptive capacity

In order to estimate the resilience of households (R) to shocks, it is necessary to first estimate the IFA, ABS, SSN,A, and AC of the households which are separately considered as latent variables themselves because they cannot be directly observed in a given survey (Alinovi et al., 2008 and 2010). Therefore, the researcher followed two-stage processes to measure the resilience of households to shocks. In the first stage, the observed variables were used to estimate the first set of latent outcome variables via a factor analysis. In the second stage, the resilience index was computed using a factor analysis of the interacting latent outcome variables estimated in the first stage. Henceforward, the overall resilience index is the summed weighted of the factors produced and quantified as:

$$
R I=\sum \mathrm{WkFk}
$$

Where $\mathrm{Wk}$ is the weights of $\mathrm{k}$ variables and $\mathrm{Fk}$ is the factors of the $\mathrm{k}$ variables. The weights are the proportions of variance explained by each factor.

\begin{tabular}{|c|c|c|}
\hline components & Indicators & Measurements \\
\hline \multirow{5}{*}{$\begin{array}{l}\begin{array}{l}\text { Income } \\
\text { food and } \\
\text { (IFA) }\end{array} \\
\text { Access to basic } \\
\text { services (ABS) }\end{array}$} & Average per household daily expenditure & Local currency(ETB) \\
\hline & $\begin{array}{l}\begin{array}{l}\text { Household } \\
\text { /household/day }\end{array} \\
\text { food }\end{array}$ consumption $\quad$ (Kcal) & Kcal \\
\hline & Access to health service & $\begin{array}{l}1=\text { if accessible } \\
0=\text { otherwise }\end{array}$ \\
\hline & Access to educational service & $\begin{array}{l}1=\text { if accessible } \\
0=\text { otherwise }\end{array}$ \\
\hline & Access to market service & $\begin{array}{l}1=\text { if accessible } \\
0=\text { otherwise }\end{array}$ \\
\hline $\begin{array}{l}\text { Social safety } \\
\text { nets (SSN) }\end{array}$ & $\begin{array}{l}\text { Amount of cash received from donor's local } \\
\text { currency/household/month. }\end{array}$ & Local currency(ETB) \\
\hline \multirow[t]{4}{*}{ Assets (A) } & Access to farm land (per hectare) & $\begin{array}{l}1=\text { if accessible at least one } \\
\text { hectare of agricultural land } \\
0=\text { otherwise }\end{array}$ \\
\hline & Access to livestock (TLU) & $\begin{array}{l}1=\text { if accessible farming animals } \\
0=\text { otherwise }\end{array}$ \\
\hline & Households access to durable assets(Tv, radio, mobile) & $\begin{array}{l}1=\text { if accessible } \\
0=\text { otherwise }\end{array}$ \\
\hline & $\begin{array}{l}\text { Households access to clean drinking water, adequate } \\
\text { sanitation, and uses electric cooking fuel }\end{array}$ & $\begin{array}{l}1=\text { if accessible } \\
0=\text { other wise }\end{array}$ \\
\hline \multirow[t]{2}{*}{$\begin{array}{l}\text { Adaptive } \\
\text { capacity (AC) }\end{array}$} & $\begin{array}{l}\text { Income generation from bamboo product (local } \\
\text { currency) }\end{array}$ & Local currency(ETB) \\
\hline & Income from diversified sources & In numbers \\
\hline
\end{tabular}

Resilience latent variables and indices 
And finally to examine the relative importance of the latent resilience dimensions to smallholders resilience to shocks, regression analysis was done through OLS (ordinary least square).

$\mathrm{RI}=\delta+\beta_{1} \mathrm{IFA}+\beta_{2} \mathrm{ABS}+\beta_{3} \mathrm{SSN}+\beta_{4} \mathrm{AST}+\beta_{5} \mathrm{AC}+\mathrm{e}$

Where, $\mathrm{R}=$ resilience, IFA $=$ Income and food access, $\mathrm{ABS}=$ Access to basic services, $\mathrm{SSN}=\mathrm{Social}$ safety nets, $\mathrm{AST}=$ Assets, and $\mathrm{AC}=$ Adaptive capacity, $\delta=$ Constant, $\beta_{1-5}=$ Coefficients of variables and $\mathrm{e}=$ error terms.

\section{Empirical Results}

In the study area, bamboo production was occupied by private, community and both private and community. In terms of bamboo cultivation, 61.11 percent of the smallholders engaged in homestead bamboo cultivation and harvest from natural forest and 38.89 percent households in the study area do not engage in bamboo cultivation. In terms of sex, male- headed households were grown bamboo in their own farm than female- headed households. The household who engaged in bamboo cultivation in their homestead from the total land 0.625 hectares or 13 percent were covered by bamboo. Regarding bamboo culms, the respondent households had on average of 2780 culms and 423 culms were selling in past 12 months and earning income 2771.61birr with the standard deviation of 5882.305 and the maximum income from bamboo culms sell is 67080 . This shows that there is a big income inequality among smallholders being engaged in bamboo production and does not engaged in bamboo production.

In the study area, the main products produced from bamboo were mats, basket, mosob, shelf, and others products and earning an annual income of 2167.93 birrs and its maximum income earning is 4800 . This finding shows that in the study area, bamboo products limited to traditional uses only, tied by obsolete technology and no more market access for the bamboo products.

From the row bamboo processing point of view, household members engaged in processing to different products and sell 324 males and 26 female, an average age of 29 and 27 for male and female respectively. This means that bamboo takes a lion share in creating of job opportunity to youths. Regarding the main purpose of bamboo in the study area is for building fences, house construction, making furniture, soil and water conservation, food and fodder respectively. The finding revealed that bamboo has multiple purposes in the study area. As shown in the result, it has environmental, fodder for animals, filling the gap of the food supply in harsh condition, fill income gaps beyond full filing households equipment.

\section{The role of bamboo on poverty alleviation and resilience to shocks}

Bamboo has a huge potential for economic development and improving the living standards of smallholders in North-West Ethiopia. Bamboo provides a meaningful advantage to smallholder farmers with little access to diversified livelihoods. The incomes generated by households add more to the agricultural economy in general and act as poverty alleviates for smallholders through the producing, processing and sale of bamboo products. This finding is similar to the finding of FAO, 2005, a thematic study prepared in the framework of the Global Forest Resource Assessment 2005.

In the study area, bamboo is mainly used for constructing houses, building fences, sources of fuel-wood, fodder for animals, handicrafts, and particularly in Benshangulgumuze region, for human food. Generally, the multiple purposes of bamboo is limited to traditional uses. This study agrees well with the finding of Fekadu Tarekegn, (2010). The contributions of highland bamboo (Yushania alpina) to rural livelihoods and status of its domestication at bule district, gedeo zone, SNNPR.

The present study also indicated that, agriculture alone could not sustain the overall proportion of the households in the studied district and that support from other activities should complement household livelihoods. To this end, the role and importance of bamboo were found to be crucial in filling income gaps and supplying the needs of households for additional income to fulfill basic needs, child educational expenses, health care, and means of surviving and resilient to different shocks.

Generally, the monthly mean incomes of 297 bamboo producers were 2965.5 while the 189 non-user mean is 1559.57 which is significant at $\alpha 0.05 \%$. This finding disagrees with the finding of Fekadu Tarekegn, (2010) that indicates the contribution of high land bamboo to rural livelihoods at Blue district was insignificant.

\section{Major shocks reported by the respondents}

Among different shocks reported by respondents, pests affect crops before harvest, a large increase in input price and death of livestock are more frequently exist in the study area. The percentage of households that reported pests affect crops before harvest, a large increase in input price and death of livestock as shocks over the last 12 months were $60.08,46.3$ and41.36 percent respectively (table 13). Regarding their severity, pests affect crops before harvest, a large increase in input price and large increase in food price were more severe than other shocks and 144(29.63 percent), 122(25.1percent) and 89 (18.31percent) households were affected by those shocks (table 14). This finding shows that to increase yield productivity, input price is a critical problem. In line with this, the produced yield by smallholders not sufficient to cover their food consumption, as a result, they had very severely damaged by incremental of food price. 
Households endeavored to cope with the negative impact of the shocks by sold livestock, obtain credit, engage on more employment, cut and sell bamboo culms, make and sell bamboo products, reduce health and educational expenditure and using bamboo for food were employed by 261(53.7 percent), 222(45.68 percent), 219(45.05 percent), 199(40.95 percent), 107(22.02 percent), 64(13.17 percent), 62(12.76 percent) households (table 15). This finding revealed that, bamboo grower smallholders using bamboo as a means of mitigating bamboo to shocks to able to resilient to shocks.

\section{Econometric analysis of multidimensional poverty status of smallholders}

Based on international conciseness of the former MDG's and nowadays sustainable development goals (SDG's), this paper employed ten indices by customizing and belonging to three dimensions education, health, and living standards. These indices compose the multidimensional poverty index two of them for education, two for health and the rest of six indices for living standards.

The weight given to the dimensions was allocated equally, thus each dimension received one third or 33.3 percent. Each index within the dimensions also allocated equal weight, so that the indices in education and health received one- sixth or 16.7 percent and indices in living standards was received one eighteen or 5.55 percent. In line with this, the analysis showed that the incidence of multidimensional poverty is 57.82 percent and 57.82 percent of the people live in multidimensional poor households. In addition to this, the intensity of multidimensional poverty is 50.38 percent and 281 smallholder farmers were deprived in 50.38 percent of the weighted indices. Onwards, 29.13 percent of smallholders were multidimensional poor.

Regarding multidimensional deprived smallholders, 162(33.3percent) bamboo producers were multidimensional poor while 189 (38.8 percent) were non-bamboo producers. This result revealed that, from 189 non-bamboo producer smallholders, 109 (57.67percent) were multidimensional deprived and bamboo has its own role on alleviating multidimensional poverty through filling the income gap of the household to fulfill the educational, health and day to day living expenditure relatively than non- producers.

\section{Econometric analysis of smallholders' resilience to shocks}

As shown in the conceptual framework, identification of applicable variable is the basic one for effective and efficient policy design. Policy intervention must focus on relevant variables to provide effective and efficient resilience building. To undertake this task, the two steps of analysis were performed. Firstly, as done in Alinovi et al (2009) factor analysis was run for each latent dimensions. And then, policy variables were selected based on their Eigenvalues, KMO, factors loadings and explained variance through generated factors.

Income and food access (IFA): Among different latent dimensions of smallholders' resilience, IFA is one of the important dimensions. IFA directly correlated with smallholders' consumption in different ways. In North-West Ethiopia especially in rural areas, smallholders' access to consumptions is a severe problem. Identification of relevant indicators that contain income and food access is necessary as each index targeted to design the policy that aims to build resilience. The main indices of IFA that employed to estimate access to consumption were household monthly expenditure and household food consumption in Kcal (Alinovi et al, 2009). The estimation of IFA through indices was after running exploratory factor analysis.

Household expenditure: this is an indicator that constitutes expenses of smallholders for the purpose of smallholders' consumption and to sustain their livelihood. This indicator is positively and directly related to smallholders' resilience to shocks.

Household food consumption: This is an indicator that indicates the number of smallholders' kilocalories intake and it is positively and directly related to stallholders' resilience to shocks. Based on these indicators factor analysis was run to estimate IFA using principal component factor method by using Stata version thirteen. Among the indices of income and food access, household expenditure indicator has taken the lion share and play a significant role in the estimation of it, whereas food consumption indicator is less important where compared to the former one.

In general, as mentioned above in the methodology part, the indicators factor weight was used to estimate IFA index. As a result, household expenditure indicator was used to estimate IFA index. It was estimated as;

$$
I F A=(0.599 * \text { factor } 1)
$$

The result obtained through this formula was further used as one of the latent variables in estimating the overall resilience index for each smallholder.

Access to basic services (ABS): Smallholders access to basic services, such as education, market and health is a basic aspect of smallholders resilient to shocks. In line with this, these variables determine the capacity of smallholders to generate income from their assets (Dercon et al, 2007).

To examine smallholders' resilience to shock ABS has been employed as a latent dimension (Alinovi et al, 2010). Kindly, ABS affects the smallholders' resilience to shocks through different ways. In North-West Ethiopian especially in rural areas, smallholders' access to the market is a crucial problem. Identification of relevant indices that constitute ABS was essential as each index targeted to design a policy that aims to build resilience. The main 
indices employed to estimate ABS was access to education, access to the market, and access to health services. The estimation of ABS through indices was after running exploratory factor analysis.

Access to education: This indicator determines the level of knowledge and understanding of smallholders to shocks and their coping strategies to recover. The accessibility was determined based on smallholders' time taken to the service via walk $\geq 30$ minutes (reference).

Access to market: One of the indices to estimate access to basic services and determine the ability of smallholders' generating income from their bamboo production.

Access to health service: This one is the third one among the most important indices of ABS. If a household is accessible to health service, is more healthy and generate income from different income sources and resilient than non-accessible. Based on these indices factor analysis was run to estimated ABS using principal component factoring method by using Stata version thirteen.

Among the indices of ABS, access to education has taken the highest share and play a significant role in the estimation of it, whereas, access to health service and access to market indices were less important when compared to access to education indicator respectively. In general, as mentioned above in the methodology part, the indicators factor weight used to estimate ABS index. As a result, access to education was used to estimate ABS index. It was estimated as;

$\mathrm{ABS}=(0.437 *$ factor 1$)$

The result obtained through this formula was further used as one of the latent variables in estimate the overall resilience index for each smallholder.

Social safety nets (SSN): Access to cash and in- kind transfer, represents the main source and mechanisms of generating additional income in most developing countries. Private and public transfers improve smallholders' annual income and contribute its role in alleviating poverty and building resilience to shocks (FAO, 2016). A Social safety net is one means of income generating activities for stallholders to cope with the adverse shocks. This dimension was estimated using cash and in- kind receives of smallholders from donors, relatives, friends, and others as indices. This index has a direct and positive relationship with the smallholders' resilience to shocks. Based on this indicator factor analysis using principal component factoring method has been run to estimate SSN using Stata version thirteen software.

The indicator, cash received from donors has effectively estimated SSN latent dimension. The relationship between the indicator and the latent dimension in the case of SSN was positively related. This finding shows that cash received from donors has its own contribution to smallholders' resilience to shocks but as the result shows, the in-kind transfer was insignificant in the estimation of SSN. This means that the in- kind receive of smallholders during adverse shocks was insufficient.

According to Ciani, (2012), SSN considered dependence on different donors, charities, non-governmental organizations nationally and internationally. In this study, the dependence of smallholders or national and international donors were totally absent. Generally, the index of SNN was estimated as;

$\mathrm{SSN}=(0.501 *$ factor 1$)$.

The result obtained through this equation was further used as a latent variable in estimating the overall resilience index for each stallholder.

ASSETS (AST): Both productive and non-productive assets of smallholders are the key elements of their livelihood, smallholders able to generate consumable and/or tradable goods and services.

This dimension measures the impact of assets on smallholder's resilience to shocks. Assets contribute a nonreplaceable role in the smallholders' risk-coping strategies. This dimension is more important components of smallholders resilience, as a result, the more smallholders own asset, the more copes from shocks and resilient to shocks.

The latent dimension assets were estimated using indices of access to a farm land, access to livestock and smallholders' access to durable assets.

Access to farmland: This variable refers total land of smallholders owned. In North-West Ethiopia, the main livelihood strategies of smallholders were agriculture specially crop production. Hence, to maintain the sustainability of their livelihood farmland has a crucial role in the life of smallholder farmers.

Access to livestock: This variable refers to the total livestock possession of smallholder farmers. Smallholder farmer's livestock is both drafting animals and productive assets. They have a crucial role in enhancing their livelihood, coping adverse shocks and become resilient to shocks through generating income and filling the income gap of smallholders from other sources.

Durable assets: this variable was measured by a local currency that smallholders expenditure to bought durable assets. They contribute their role in coping shocks and stallholders to become resilient to shocks through providing information on the situation and strategies to mitigate shocks and fill the income gap of smallholders during harsh condition by selling them. Based on these indices a factor analysis was run to compute Asset using principal factoring method.

The indicators access to farmland and access to farm livestock has taken the highest factor loading relatively 
from access to durable assets and play a significant role in the estimation of it. This finding shows that, as smallholders' access to farmland and farm livestock, the households able to produce more, generate income, sustain their livelihood and build capacity to cope shocks and becomes resilient to shocks. Based on the coefficient scores of indices the asset index was estimated as;

$\mathrm{A}=(0.334 *$ factor $1+0.332 *$ factor 2$) / 2$

The result found through this equation was further used as one of the latent variables in estimating the overall resilience index for each smallholder.

Adaptive capacity (AC): To measure the smallholder farmers' capacity to mitigate and interact to shocks adaptive capacity (AC) is the main latent dimension of resilience (Alinovie et al, 2010). Adaptive capacity presents the ability of smallholders adopts to shocks. If the smallholders have diversified income sources and shock mitigating strategies, become resilient to shocks.

The latent dimension AC shows the ability of smallholders to adopt and cope to the new situation and build diversified sources of new livelihood. Smallholders' having numerous income generating sources decrease the negative effect of adverse shocks (FAO, 2016). Income farm bamboo production and number income sources observable variables where selected as indices of AC of smallholders to shocks.

Income farm bamboo: In North-West Ethiopia, income generating from bamboo has a crucial role in filling the income gap between crop production and animal raring. In the study area, bamboo becomes means of livelihood for smallholders beyond supporting the income gap from agriculture.

Income from diversified sources: As FAO, 2016 states that a smallholder have multiple sources of income, the probability of surviving the negative effect of shocks high and becomes resilient than smallholders having unique sources of income.

The variables have positive and direct relations with smallholders' resilience. On top of these, observable variables factor analysis was run to estimate Ac using principal component factor method. Among indicators of Ac income from bamboo production is more important variable in estimating it than income from diversified sources. As a result, it has relatively higher explained the power of variance. The result shows that, as smallholders engaged in the bamboo production and multiple income sources, the house held generate more income and develop their capacity to adopt and cope with shocks and become resilient to shocks. However, the relation among income from bamboo production was related negatively. This shows that due to market inaccessibility the income generated from bamboo was not as its massive potential. Based on the factor weight of variables the index of $\mathrm{AC}$ was computed as:

$$
\mathrm{AC}=(0.502 * \text { factor } 1)
$$

The result obtained through this formula was further used as a latent variable in estimating the overall resilience index for each smallholder farmers.

\section{Econometrics analysis of small holder overall resilience index result estimation}

On top of the above session, attention was given to computing each resilience latent dimension individually using factor analysis of principal component factor. Now, it is time to assemble each latent dimension to compute resilience index of smallholders. The latent dimension computed earlier becomes covariate in the estimation of smallholder farmers' resilience index. Suppose that all computed factors were normally distributed with mean zero and variance equals to one, a factor analysis was run using principal component factoring method through software package of stata version thirteen.

As expected the correlation of dimension ABS, AC and factor one correlated positively. This result shows that these dimensions were sufficient to estimate resilience to shocks whereas, IFA, SSN and AST dimensions captured by factor two. The indicator AC and SSN had heavy factor loading and lower unique variances and play a significant role in the estimation of overall resilience index of smallholders. This result shows that the smallholders' engaged in bamboo production, having the capacity to adopt, benefit and cope with shocks and becomes more resilient to shocks. Especially, AC dimension has greater factor loadings and shows it as a policy variable and policy intervention place on it. Relatively, ABS in factor has less factor loading but still important loading in the estimation of resilience.

Within the factors weight of each dimension, the overall resilience index estimated as; $\mathrm{RI}=(0.229 * I F A+0.206 * A B S+0.197 * S S N+0.191 * A C+0.174 * A S T)$

The resilience index is a multiple component indexes that show the status of smallholders' resilience to shocks, no universally consensus and accepted cut off point and line of a segment to delineate resilient smallholders from non-resilient. However, Guyu et al (2013) contribute his effort as a cut of point to delineate resilient from nonresilient, in which RI less than 1.00 non- resilient, and RI $\geq 1.00$ (one) resilient and using this cut of point, 233 smallholders (47.94 percent) resilient and 253 smallholders (52.06 percent) non-resilient. However, resilience to shocks from the perspective of bamboo production engagement, 80.15 percent of bamboo producer smallholders resilient while non-produce 32.92. This finding shows that there is a big difference in resilience to shocks being engaged in the production of bamboo and which is statistically significant. 


\section{Relative importance of latent dimensions on smallholders' resilience measurement}

The contributions of latent dimension on smallholders' resilience do not equal. Relatively some have more value than others in estimating smallholders' resilience. To identify the relative importance of each variable on estimating smallholders resilience, regression analysis has run through ordinary lest square (OLS). The resilience index (RI) used as a dependent variable and the five latent dimensions, income and food Access (IFA), access to basic service (ABS), social safety net (SSN), and Asset (AST) and Adaptive capacity (AC) was used as explanatory variables. The regression analysis was computed as;

$$
R I=0.018+0.044 * I F A-0.096 * A B S+0.056 * S S N-0.081 A S T+0.041 * A C
$$

The ABS, AST, and AC contribute higher coefficients and play a significant role in the estimation of smallholder resilience. The implication of the finding is that a 0.081 unit decrease in smallholder s' access to their asset increases their resilience by 1 standard diversion. This finding shows that when smallholders faced with shocks, mitigating shocks by depleting their asset. However, this type of activity hurts their asset stock in the long run. In addition to this, a 0.096 decrease in ABS their resilience increases by 1 standard deviation. This finding revealed that at the shock, season smallholders mitigate shocks through decreasing the educational and heath expense, as a result of this, temporarily their resilience increase at the cost of their level of understanding and health insurance. Contrast, a 0.041 unit increase in AC in smallholders increases their resilience by 1 standard deviation.

The relative difference in importance of each latent dimensions of smallholders' resilience to shocks has clear policy implications. To improve the smallholders' resilience, policy makers and implementation can place their attention on relatively important latent dimensions.

Post- estimation test (Multicollinearity, Heteroskedasticity, and normality) of OLS model has been done and the model was well fitted.

\section{Conclusions and policy implications}

In North-West Ethiopia, smallholders are engaged in different types of livelihood strategies. Among these, bamboo is one of the means of living strategies and has a crucial importance as coping mechanisms to fill the income gap of smallholders' expenditure to sustain their livelihood. In addition to this, the purpose of bamboo appreciated above all due to its domestically multiple purposes.

The study areas, the socio-economic impact of bamboo on improving the wellbeing of smallholders are higher. In line with this, the main purpose of bamboo was income generation, fence utilization, house construction, food and fodder and for furniture.

However, the systems of bamboo utilization were limited to traditional use and obsolete technology.

The smallholders' access to basic services especially road and market more beneficial to their bamboo product than inaccessible smallholder bamboo growers. The role of bamboo in improving the wellbeing of smallholders' are not unidimensional rather it is multiple purposes, such as it contributes its role to child school enrolment, construction of toilet for their sanitation and generate income to bought health treatment equipment like a drug. Hove ever, bamboo multiple purposes were limited in when compared with its' massive potential due to the main constraints of a market in accessibility and using of obsolete technology.

Multidimensional poverty in this paper defined as, multidimensional deprivation in education, health, and living standards on bamboo producing smallholders and measured using the latent dimensions education, health, and living standards by employing their proxy observable indices. MPI pays a significant role in measuring smallholders' multidimensional poverty status. The multifaceted measure of poverty can be expressing a more detail picture of smallholders' how they are deprived. Multidimensional measures of poverty create a chance that enables policymakers to place more attention on the high average weight of deprived latent dimensions and observable indices. Among the respondent smallholder formers, 29.13 percent is multidimensional poor. The incidence of poverty and intensity of multidimensional poverty in the smallholders were 57.82 and 50.38 percent respectively.

The contribution of education, health and living standards for MPI is 41.09, 35.08 and 651.9 Percent respectively. According to the observable indices of the deprivations household members 5 years schooling, malnourishment and households cook with the dirty material were higher than others.

Regarding shocks, natural disaster and economic related shocks like pests affect crops before harvest and a large increase in input price, in the North- West Ethiopia is a dominant cause to smallholders' to sold their productive animals and fixed assets like land and reduce educational and health expenses. The options that smallholders' stand with those shocks depends on the way access to them through abilities and activities. The latest and updated ways of smallholders' withstands to coping shocks related effects are through resilience.

Resilience is a set of comebacks that may counter the fundamental and stochastic influences that allow a household or other unit to be susceptible when bare to some set of shockwaves and stressors while Shock is an event that can trigger a decline in well-being (Word Bank, 2001). In the study area, household level survey data was collected. Smallholders' resilience to shocks was measured using RIMA model (FAO2005). This paper further 
adopts multiple regression models to explore the relative importance of each latent variable in smallholders' resilience index. Due to inaccessibility of suitable panel data set the static resilience analysis was done. However, resilience index defined as a function of income and food access (IFA), access to basic service (ABS), social safety net (SSN), Asset (AST) and adaptive capacity (AC) as latent variable and estimated using proxy variables for each and computed separately using factor analysis of principal component factor Method. The identified proxy variables for each latent dimensions was statistically significant. The result of each latent dimensions in estimation becomes covariate to measure resilience index. Generally, 47.94 percent of the surveyed smallholders' were resilient and 52.06 percent were non-resilient to shocks. Regarding smallholders engaged in bamboo production, 85.15 percent of the users' resilient while the non-user 32.92 percent. Thus, the resilience capacity of bamboo user smallholders' in North-West Ethiopia is highly strong. All of the five latent dimensions in the estimation of resilience to shocks were important. AC was played the crucial role in estimation. As a general, the finding has indicated interventions should have to place on dimensions prioritized based on their weight in order to lift out smallholders' from shock effects and to build resilience. In addition to these, interventions to improve smallholders' AC observable variables are an intervention area. Especially, bamboo growing related problems like market accessibility, value chain problems are a crucial intervention area to boost up the bamboo production. In the study area, bamboo production is a key means of livelihood to smallholders' resilience to shocks.

As the result revealed that, in North-West Ethiopian, bamboo plays its pivotal role in improving smallholders' in one and another way. Among its multiple purposes, diversification and filling the income gap of smallholders' during devastating their main farming income sources by shocks were the crucial one. However, from the perspective of bamboo potential in the study area, especially in Bibugn woreda and Awi zone, utilization of bamboo is limited due to market inaccessibility problem, no different factories demand to bamboo production. As a result of this, the government should have to look towards these problems to solve and ensure the multiple purposes of bamboo up to its maximum potential. In line with this, to scale up the current production and to provide demand for bamboo production, setting bamboo production and utilization policy and strategies nationally is the optional way to improve and sustain the bamboo livelihood of smallholders' in Ethiopian.

To utilize the current bamboo potential efficiently, to scale up bamboo production in the future for sustainable utilization, organizing farmers in bamboo cooperative, providing extension service on bamboo, providing technical training how to use bamboo in different way, proper processing of bamboo, value chain, creating market chain should have to governmental policy and strategies intervention areas.

Internationally, there is a consensus on post-2015 sustainable development goals. Among 17 development goals ending poverty and building, resilience is the first and eleventh issues respectively.

Before and in 2015, the government has performed a different activity to reduce poverty targeted it as the first MDG's goals. However, it was not enough and cannot be lifted out smallholders from multiple deprivations and vulnerable to risks. As a result of this, to achieve the first and eleventh target of sustainable development goals, the government should have to open the eye on bamboo production and showed have to consider bamboo is a major means of livelihood for smallholders.

As the result and discussion part above shows that, smallholders faced by different shocks and its effect leads to multiple deprivations and smallholders' use bamboo as coping strategies even as a food especially in Assossa zone. As result of this, government places the hand on bamboo production related problems mentioned above.

According to the multiple deprivations of smallholders, all indices contribution to multidimensional poverty is high and especially, household- years of schooling, malnourishment and improving households cooking material should have to target in sustainable development goals to improve their performance. So that government's policy intervention should have to implement at the grass root level to lift out smallholders from their multiple deprivations.

Regarding small holds resilience to shocks, strengths and adopting shocks mitigating strategies are essential to building and smallholders' become resilient. As the result revealed that, AC plays a crucial role in the resilience of smallholders to shocks. As a result of this, the government policy interventions aim to improve the performance and place attention on improving bamboo production and access the bamboo production to market. In addition, female- headed smallholders have less resilient than male- headed smallholders'. Hence, governments place its policy intervention and focus on female- headed smallholders' in advance to solve shock related problems.

\section{REFERENCES}

Abdikadir.M.(2013). Dimensions and Determinants of Poverty in Agropastoral Households of Jijiga District, Somali National Regional State, Ethiopia (Doctoral dissertation, Haramaya University).

Abebe Y., Teshome T., Mohammed A.and Mesfin H. (2004). Conservation of genetic resources of non-timber forest products in Ethiopia: Availability uses and trends of Non-timber forest products in Mendi Area, West Wellega; In socio-economic importance and resource potential of non- timber forest products of Ethiopia Addis Ababa, Ethiopia. PP. 118-130.

Alinovie, L., D’Errico, M., Mane, E., \& Romano, D. (2010). Livelihoods strategies and household resilience to 
food insecurity: An empirical analysis to Kenya. In conference organized by the European Report of Development, Dakar, Senegal, June (pp. 28-30).

Alkire, S. and Foster, J. (2011). Counting and Multidimensional Poverty Measurement. Journal of Public Economics.

Alkire, S. and Robles, G. (2016). "Multidimensional Poverty Index 2016: Brief Methodological Note and Results". Available at: www.ophi.org.uk/multidimensional-poverty-index/.

Alkire, S. and Santos, M. E. (2010). Acute multidimensional poverty: A new index for developing countries, Human Development Research Paper July 2010, Oxford Poverty and Human Development Initiative, University of Oxford.

Alkire, S., and M. Santos. (2010). "Acute Multidimensional Poverty: A New Index for Developing Countries." Human Development Research Paper 2010/11. UNDP-HDRO. New York.

Ambrose-Oji, B. (2003). The contribution of NTFPs to the livelihoods of the 'forest poor': evidence from the tropical forest zone of south-west Cameroon. International Forestry Review. 5(2):106-117.

Amede, T., Belachew, T., \& Geta, E. (2001). Reversing the degradation of arable land in the Ethiopian Highlands.

Andargatchew, A. (2008). Value Chain Analysis for Bamboo Originating from Shedem Keble, Bale Zone. MBA. Faculty of Business and Economics, School of Graduate Studies, Addis Ababa University. Unpublished. Addis Ababa, Ethiopia.

Arsema A. (2008). Value Chain Analysis for Bamboo Originating from Shedem Kebele, Bale Zone. MSc. Thesis, Addis Ababa University, Ethiopia, 2008; P. 94.

Assaye, Y., Selassie, Y. G., \& Ayele, B. (2014). Farmers' Perception on Highland Bamboo (Yushania alpina) For Land Resource Conservation in Banja District, Northwestern Ethiopia. Woodpecker Journal of Agricultural Research. 3(1):001-009.

AWZAD. (2007). Awi zone Agriculture Department Annual Report. Amharic version.

Bapu V. Girmay T. Megan RunsoevilleDaniel M. (2012). Resilience and Livelihoods Change in Tigray, Ethiopia, October 2012

Brias, V., \& Hunde, T. (2009). Bamboo cultivation manual: Guidelines for cultivating Ethiopian highland bamboo. East Africa Bamboo Project Document, UNIDO.

Central Statistical Agency of Ethiopia (CSA, 2007). The 2007 National Statistics of Population; Central Statistical Agency of Ethiopia: Addis Ababa, Ethiopia, 2007.

Cherla A, (2008). Vision for Bamboo in India Opportunities and Challenges.

Chernet, T. (2009). Baseline Census Report. Bamboo as sustainable biomass energy: a suitable alternative for firewood and charcoal production in Africa. INBAR.

Chirwa, P. and Meliczek, H. (2014). First international forum on current state and future opportunities for a unique renewable resource in Africa. International Seminar on Bamboo in Africa. University of Pretoria.

Choudhary M.L. and Shri K.S. (2008). Proceeding of 3rd International Conference on Improvement of Bamboo Productivity and Marketing for Sustainable Livelihood, New Delhi, India. 15th - 17th April, 2008; pp 6-215.

CIA: Central Intelligence Agency. (2014). Ethiopia: In the World Factbook. Retrieved from https://www.cia.gov/library/publications/the-world

Coates, J. Maxwell, D., Webb, P., \& Wirth, J. (2010). Fit for purpose? Rethinking food security responses in protracted humanitarian crises. Food policy, 35(2), 91-97.

Deininger, K., \& Jin, S. (2006). Tenure security and land-related investment: Evidence from Ethiopia. European Economic Review. 50(5):1245-1277.

Department for International Development (DFID), UK. (2011). "Defining Disaster Resilience: A DFID Approach Paper." London: DFID.

Desalegn, G., \& Tadesse, W. (2014). Resource potential of bamboo, challenges and future directions towards sustainable management and utilization in Ethiopia. Forest Systems. 23(2):294-299.

Embaye, K. 2000. The indigenous bamboo forests of Ethiopia: An overview, A journal of the human environment 29(8):518-521.

Embaye, K., L. Christersson, S. Ledin \& Weih M., (2003). Bamboo as bioresource in Ethiopia: Management strategy to improve seedling performance (Oxytenanthera abyssinica). Bioresource Technology 88(1):33-39.

Embaye, K., Weih, M., Ledin, S., \& Christersson, L. (2005). Biomass and nutrient distribution in a highland bamboo forest in southwest Ethiopia: implications for management. Forest Ecology and Management. 204(2):159-169.

Endalamaw, T. B., Lindner, A., \& Pretzsch, J. (2013). Indicators and Determinants of Small- Scale Bamboo Commercialization in Ethiopia. Forests. 4(3):710-729.

Ensermu K.Tamrat B., Alemayehu G. and Gebremedhin H. (2000). A Socio-Economic Case Study of the Bamboo Sector in Ethiopia: An Analysis of the Production-to-Consumption System. Addis Ababa March 2000.

Ethiopia. Doctoral Dissertation, Swedish University of Agricultural Sciences, Uppsala, Sweden.

FAO (Food and Agriculture Organization of the United Nations)(2006). Global Forest Resources Assessment 
Updates 2005: Country report on bamboo resources (final draft): Addis Ababa, Ethiopia. Working Paper 117. FAO, Rome, Italy, and INBAR (International Network for Bamboo and Rattan), Beijing, China.

FAO (Food and Agriculture Organization) (2012). World Poverty: A Look at Causes and Solutions; by Vincent Wilmot; 166 Freeman Street; Grimsby, UK.

FAO, UN and INBAR. (2005). Global forest resources assessment, country report on bamboo resources (final draft), Addis Ababa, Ethiopia. Working Paper, No 117, Rome.

FAO: Food and Agriculture Organization of the United Nations. (2005). "Global forest resource assessment 2005: progress towards sustainable forest management”. FAO Forestry Paper 147. FAO: Rome.

Fekadu T., (2010). The contribution of highland bamboo (Yushania alpina) to rural livelihoods and status of its domestication at bule district, gedeo zone, SNNPR.

Ganeshaiah, Smitha Krishnan, R. Ramya. (2004). Livelihood gains and ecological cost of non-timber forest product dependence: assessing the roles of dependence, ecological knowledge and market structure in three contrasting human and ecological setting in south India. Environmental Conservation 31 (3): 242-253

Harrison, E. (2002). The problem with the locals': partnership and participation in Ethiopia. Development and Change. 33(4):587-610.

IFAD (International Fund for Agricultural Development),( 2011). Enabling Poor Rural People to Overcome Poverty; Rural Poverty Report; New Realities, New Challenges, New Opportunities for tomorrow's generations. Addis Ababa: Federal Democratic Republic of Ethiopia.

INBAR (International Network for Bamboo and Rattan). (2010). Study on Utilization of Lowland Bamboo in Benishangul Gumuz Region, Ethiopia.

INBAR (International Network of Bamboo and Rattan). (2008). Mainstreaming Pro-Poor Livelihood Opportunities with Bamboo. Working Paper: INBAR. 66.

INBAR. (2010). Study on utilization of lowland bamboo in Benishangul-Gumuz Region, Ethiopia.

INBAR. (2015).How countries can harness these resources to add value to action plans for sustainable development: Preparation for the UN Summit for the Adoption of the Post-2015 Development Agenda, August 2015.

Kassa, B. Z. (2009). Bamboo: An Alternative Building Material for Urban Ethiopia: a Project Report M.S. California Polytechnic State University, Unpublished San Luis Obispo, CA.

Kassahun Embaye. (2003). Ecological aspects and resource management of bamboo forests in

Kelbessa, E., Bekele T., Gebrehiwot A. \& Hadera G., (2000). A Socio-Economic Case Study of the Bamboo Sector in Ethiopia: An analysis of the production-to-consumption system. Addis Ababa University, Addis Ababa, Ethiopia.

Kibwage, J.K. and Misreave, S.E. (2011). The value chain development and sustainability of bamboo housing in Ethiopia. International Network for Bamboo and Rattan, Beijing, China.

Krzyzanowski. J., Li, Q., Cao, L. and Liu, Y. (2014). Changes in vegetation photosynthetic activity trends across the Asia-Pacific region over the last three decades. Remote Sensing of Environment, 144: 28-41.

Levang, P., Dounias, E., \& Sitorus, S. (2005). Out of the forest, out of poverty? Forest trees and Livelihoods. 15(2):211-235.

Lobovikov, M. 2006. Introduction to the Global Bamboo Resources Statistics, International Bamboo Inventory Training Workshop, 24 October - 04 November 2005 in Beijing and Zhejiang Province, China.

Marshall, E., Schreckenberg, K., \& A.C. Newton. 2006. Commercialization of Non-timber forest products. Factors influencing success, Lessons learned from Mexico and Bolivia and policy implications for decisionmakers. UNEP-WCM, 136pp.

McKenna, Ed (2013). "Ethiopia leads the bamboo revolution," Inter Press Service (IPS).The Guardian, April20,2013,http://www.theguardian.com/environment/2013/apr/10/ethopia-bamboo

Mekonnen, A., Bekele, A., Fashing, P. J., Hemson, G., \& Atickem, A. (2010). Diet, activity patterns, and ranging ecology of the Bale monkey (Chlorocebus djamdjamensis) in Odobullu Forest, Ethiopia. International Journal of Primatology. 31(3):339-362.

Mirjam A.F., Ros-Tonen and K. Freerk Wiersum. 2003. The importance of non-timber forest products for forestbased rural livelihoods: an evolving research agenda. Paper presented at the GTZ/CIFOR international conference on livelihoods and biodiversity. 19-23 May 2003. Bonn, Germany

MOFED (Ministry of Finance and Economic Development), (2012). Ethiopia's Progress towards Eradicating Poverty: An Interim Report on Poverty Analysis Study (2010/11) report march, 2012.Addis Ababa, Ethiopia.

Mohammadi, M., khalifah, Z. and Hosseini, H. (2010). Local people perceptions toward social, economic and environmental impacts of tourism in Kermanshah (Iran). Asian Social Science, 6: 11, ISSN 1911-2017 EISSN 1911-2025.

Morris J. (2002). Bitter bamboo and Sweet living: impacts of NTFP conservation activities on poverty alleviation and sustainable livelihoods.

Nations Development Assistance Framework 2012-2015. United Nations Country Plan; March 2011. 
Nongdam, P. and Tikendra. L. (2014). The nutritional facts of bamboo shoots and their usage as important traditional foods of Northeast India. International Scholarly Research Notices, pp 1-17. ISSN-0974-2441.

Nygren, A., Lacuna-Richman, C., Keinänen, K., \& Alsa, L, (2006). Ecological, socio- cultural, economic and political factors influencing the contribution of non-timber forest products to local livelihoods: case studies from Honduras and the Philippines. Small-scale Forest Economics, Management and Policy. 5(2):249-269.

Perez M.R., Ousseynou Ndoye, Antoine Eyebe and Atie Puntodewo (2000). Spatial characterization of non-timber forest products markets in the humid forest zones of Cameroon. International Forest review

Poverty Analysis and Data Initiative (PADI) held on May 6-8 2004 in Mombasa, Kenya; Department of Economics, Addis Ababa University, Ethiopia. May 30, 2004.

Rao, A.N. (1999). Anatomical Studies on Certain Bamboos Growing in Singapore. Department of Botany, National University of Singapore, Lower Kent Ridge Road, Singapore 0511: 209-225.

Reynolds, T. W., Farley, J., \& Huber, C. (2010). Investing in human and natural capital: An alternative paradigm for sustainable development in Awassa, Ethiopia. Ecological Economics. 69(11):2140-2150.

Ross, K. C., Clark, L. D., \& Padgett, T. C. (2006). Air University sampling and surveying handbook: Guidelines for planning, organizing, and conducting surveys. University Press of the Pacific.

Sabina Alkire (2009). Multidimensional Poverty measures: New potential, The 3rd OECD World Forum on "Statistics, Knowledge and Policy" Charting Progress, Building Visions, Improving Life Busan, Korea - 2730 October 2009.

Sen, A. (2000). A decade of human development, Journal of Human Development 1(1), pp. 17-23.

Sen, Amartya (1979). "Equality of what?" The Tanner Lecture on Human Values.

Sen, Amartya (1983). "Poor, relatively speaking”, Oxford Economic Papers, New Series, vol. 35, No.2, Julio.

Sen, Amartya (1985). "Well-being, agency and freedom: the Dewey Lectures 1984", The Journal of Philosophy, vol. 82, No.4.

Sen, Amartya (1997). "From income inequality to economic inequality", Southern Economic Journal, vol. 64, No. 2.

Sertse D., Tesfaye D. , Kassahun B., Mehari A., Yared K., Negash E. and Sintayehu E.(2011). Mass flowering and death of bamboo: a potential threat to biodiversity and livelihoods in Ethiopia. J Biodivers Environ Science, 2011; $1: 16-20$

Shackleton, S.E.,(2005). Analysis, Household Wealth Status and Natural Resource Use in the Kat River Valley, South Africa. Ecological Economics (in press).

Sosola-Banda B.G and Johnsen F.H. (2005). Rural livelihoods on Bamboo handicraft making and culm vencding in Mvera, Malawi. Journal of Bamboo and Rattan. Vol 4, No 1. 93-107.

Stephen, C., Dorothee, H., Jerker, T., Dan, L. and Justin, V. (2011). Mitigating climate change through restoration and management of coastal wetlands and near-shore marine ecosystems challenges and opportunities, February 16, 2015.

Tadesse, M. (2006). Bamboo and Rattan Trade Development in Ethiopia. Bamboo for the Environment, Development and Trade.

Takahashi, J. (2006). Bamboo in Latin America: Past, present and future. In: Bamboo for the Environment, Development and Trade: International Bamboo Workshop.

Tassew W., (2004). The Experiences of Measuring and Monitoring Poverty in Ethiopia;

Tesfaye Gedefaw (2013). Rural household's poverty and vulnerability in Amhara region: case study in Gubalafto Woreda,

Teshome Adugna,(2012). Economic Growth, Development and Poverty in Ethiopia.

Tinsley, Bridget, (2014).Bamboo harvesting for household income generation in the Ethiopian highlands: Current conditions and management challenges.

UNDAF (United Nations Development Assistance Framework),( 2011). Ethiopia United

UNDP (2011). Definition and types of shocks and coping strategies to be monitored: Technical Workshop on "Monitoring Household Coping Strategies during Complex Crises" Sommerset Millennium Hotel March, 2011.

UNICEF, (2015). UNICEF Annual Report 2015, Ethiopia.

UNIDO (2007). Bamboo Market study in Ethiopia. Technical Paper. Based on the Work of Dr.Berhanu Adenew, EEPRI, and Ethiopia.

UNIDO (2009). Bamboo Sector Strategy Framework (BASSF) Framework Document for Discussion (Draft) Prepared for the Government of the Federal Democratic Republic of Ethiopia Chen.B. XU.G, Coops, C.N., Ciais. P., Innes.L.J, Wang.G, Myneni.B.R, Wang.T.,

United Nations (2011). The Millennium Development Goals Report, New York, NY: United Nations.

USAID (2012). Building Resilience to Recurrent Crisis: USAID Policy and program Guidance, December 2012.

Van der Wal, Wilg. Abdunaser Bedri and Teshome Mejour. (2012). Quick Bamboo Forest Assessment. Shedem village and kebeles. 
Wang, X. (2006). Comparative Analysis and Policy Recommendations on Developing Bamboo Resource Tenure Systems in Asia and Africa. Joint Project in Cooperation with International Network for Bamboo and Rattan, Beijing, China, and World Forest Institute, Portland, Oregon, U.S.A.

Yamane, T. (1967). Elementary Sampling Theory. 1st Edn. Prentice-Inc., Englewood Cliffs, New Jersey, USA

Yemiru, T., Roos, A., Campbell, B. M., \& Bohlin, F. (2010). Forest incomes and poverty alleviation under participatory forest management in the Bale Highlands, Southern Ethiopia. International Forestry Review. 12(1):66-77.

Yemishaw, Y., Teketay D., Worku A. \& Yohannes Y., (2009). Gathering storm: The fate of forestry research and development in Ethiopia. Pp. 11-38 in Proceedings of Forestry at Cross Road in Ethiopia: Addis Ababa, Ethiopia.

Yenesew A., Yihenew G., and Belayneh A., (2013). Journal of Agriculture and Biodiversity Research ISSN 2277 0836; Volume 2, Issue 7, pp. 151-159; September, 2013.

Yigardu M, Mengistie K. (2009). Status of bamboo resource development, utilization and research in Ethiopia: a review, Vol.11 (1): 63-81. Ethiopian Journal of Natural Resources. Ethiopian Society of Soil Science, Addis Ababa, Ethiopia.

Zenebe M., Adefires W., Temesgen Y., Mehari A., Demel T., and Habtemariam K. (2014). Bamboo Resources in Ethiopia: Their value chain and contribution to livelihoods. Ethno Botany Research and Applications.

Zenebe M., Adefires W., Temesgen Y., Mehari A., Demel T., and Habtemariam K. (2014). Bamboo Resources in Ethiopia: Their value chain and contribution to livelihoods.

BWAO (2007). Bibugn Woreda Agriculture Office Annual Report. Un published annual report of Amharic version.

BWFEDO (2007). Bibugn Woreda Finance and Economic Development Office Annual Report. Unpublished annual report of Amharic version.

Temesgen Kebede, Jema Haji, Belaineh Legesse, and Girma Mammo (2016). "Econometric Analysis of Rural Households' Resilience to Food Insecurity in West Shoa, Ethiopia.” Journal of Food Security, vol. 4, no. 3 (2016): 58-67. doi: 10.12691/jfs-4-3-2. 